\title{
ANALISIS USAHA INDUSTRI RUMAH TANGGA MELALUI PENGOLAHAN KUE KERING
}

\author{
Rahmi Widyanti, Susiladewi, dan Erni Alfisah \\ Fakultas Ekonomi, Universitas Islam Kalimantan \\ E-mail : rahmiwidyanti@yahoo.com
}

\begin{abstract}
ABSTRAK
Setiap usaha yang dijalan baik kecil maupun besar tujuannya adalah untuk memperoleh laba. Untuk mengetahui sejauhmana keuntungan yang diperoleh dari usaha/bisnis yang dijalankan memerlukan pencatatan yang seksama. Pencatatan baik pengeluaran maupun penghasilan usaha harus dilakukan dengan teliti sehingga analisis dan perhitungan laba rugi bisnis yang dijalankan dengan hasil yang mencerminkan potensi usaha. Kelurahan Tatah Pamangkih luar terletak di Kabupaten Banjar merupakan daerah pertanian, dimana penduduknya sebagian besar $(57 \%)$ bermukim di wilayah persawahan dan sebagian besar $(53 \%)$ dari mereka (keluarga) menggantungkan nafkah/ kehidupannya dari laut sebagai petani tradisional. Selama ini sudah pernah dilakukan sosialisasi dan penyuluhan tentang merancang bisnis kecil-kecilan oleh kelompok ibu-ibu namun belum memberikan hasil yang memadai. Hal ini disebabkan tidak dilakukannya analisis usaha dengan baik. Melalui kegiatan pengabdian kepada masyarakat ini berupaya memberikan pengetahuan tentang bagaimana menganalisis atau menghitung harga sebuah produk sehingga dapat memberikan keuntungan bagi produsennya.
\end{abstract}

Kata kunci : Analisis Usaha, industri rumah tangga

\section{PENDAHULUAN}

Pencatatan adalah hal yang sangat penting dalam menjalankan setiap jenis usaha, termasuk usaha pengolahan kuekue kering. Pencatatan baik pengeluaran maupun pendapatan dalam jumlah besar atau kecil harus dilakukan dengan teliti sehingga analisis dan perhitungan laba rugi suatu usaha bisa dilakukan dengan hasil yang mencerminkan potensi usaha. Dalam sistem usaha yang masih bersifat tradisional, pencatatan tetap diperlukan walaupun fungsi usaha tersebut hanya sebagai usaha sampingan atau hanya sekedar untuk memenuhi kebutuhan gizi dalam keluarga. tenaga kerja dalam keluarga tetap diperhitungkan dalam pengolahan kue-kue kering walaupun dilakukan sendiri oleh pemilik.

Pengolahan kue-kue kering yang berorientasi bisnis dan mengharapkan keuntungan besar, seluruh pengeluaran dan pendapatan harus diperhitungkan. Ada biaya-biaya yang secara riil tidak dikeluarkan tetapi harus tetap diperhitungkan, misalnya gaji pemilik usaha yang turut bekerja dalam usahanya sendiri, bunga bank dan 
beberapa biaya lain. Meskipun bekerja dalam usahanya sendiri, gajinya harus dipertimbangkan untuk memperoleh keuntungan yang sebenarnya. Demikian juga bunga bank sekalipun modal yang digunakan adalah modal sendiri. Biayabiaya yang dikeluarkan untuk membeli peralatan, transportasi, pembangunan toko dan berbagai sarana penunjang yang tidak habis dipakai untuk satu kali masa produksi diperhitungkan sebagai biaya penyusutan yang didasarkan pada umur pakainya.

Agar perhitungan secara ekonomis dapat dilakukan secara akurat maka perlu dilakukan pemisahan antara biaya investasi dan biaya produksi (variabel) yang dikeluarkan selama masa usaha.

Kelurahan Tatah Pamangkih luar terletak di Kabupaten Banjar merupakan daerah pertanian, dimana penduduknya sebagian besar $(57 \%)$ bermukim di wilayah persawahan dan sebagian besar (53\%) dari mereka (keluarga) menggantungkan nafkah/ kehidupannya dari laut sebagai petani tradisional.

Tidak berbeda dengan petani tradisional di daerah lain, petani tradisional di kelurahan Tatah Pamangkih Luar menghadapi kesulitan memenuhi tuntutan kebutuhan hidup minimalnya karena hasil usaha (pendapatan) yang diperoleh dari pekerjaannya masih rendah dan tidak menentu. Kebijakan pemerintah menaikan harga BBM secara bertahap memicu kenaikan harga barang (seperti sembako) dan mendorong tingkat inflasi sehingga menurunkan daya beli masyarakat, khususnya petani tradisional, semakin berkurang, meskipun tingkat pendapatan riilnya naik. Petani tradisional juga bersaing dengan petani yang dikategorikan semi modern dan modern dan menghadapi cuaca serta musim yang tidak menentu yang mengganggu aktivitas mereka. Untuk itulah diperlukan suatu model pemberdayaan ekonomi petani tradisional daerah pesisir dalam upaya meningkatkan pendapatan mereka. Menurut Kusnadi (2009) pemberdayaan masyarakat diartikan sebagai usahausaha sadar yang bersifat terencana, sistematik, dan berkesinambungan untuk membangun kemandirian sosial, ekonomi, dan politik masyarakat dengan mengelola potensi sumber daya yang mereka miliki untuk mencapai kesejahteraan sosial yang bersifat berkelanjutan.

Salah satu bentuk pemberdayaan masyarakat adalah berupa memberikan 
kesadaran terhadap adanya peluangpeluang baru dalam meningkatkan kesejahteraan hidupnya dan bisa juga dengan memberikan pelatihan-pelatihan dalam membuka usaha secara mandiri.

Berdasarkan penjelasan di atas, maka perlu di adakan pelatihan kepada masyarakat terutama yang berdomisili di kelurahan Tatah Pemangkih Laut Kabupaten Banjar terkait analisis usaha mandiri.

Tujuan dari kegiatan ini adalah untuk menambah wawasan dan pegetahuan dalam menganalisis bagi ibu-ibu petani yang berdomisili di wilayah Tatah Pemangkih Kabupaten Banjar.

\section{KHALAYAK SASARAN}

Kelompok Tani yang ada di desa Tatah Pemangkih ini bekerja sama dengan kelompok ibu-ibu PKK yang memiliki kegiatan sebagai petani di wilayah tersebut.

Berdasarkan pengamatan di lapangan, masyarakat desa sudah merintis beberapa usaha kecil, namun masih kesulitan dalam melakukan analisis usaha secara mandiri.

Dalam kegiatan penyuluhan dan sosialisasi ini yang menjadi sasaran kegiatan adalah masyarakat dan ibu-ibu
PKK yang bekerja sebagai petani di desa Tatah Pamangkih kecamatan Tatah Pemangkih kabupaten Banjar.

\section{METODE}

Kegiatan penyuluhan dan sosialisasi ini merupakan bagian dari Pengabdian pada Masyarakat dilakukan dengan memberikan ceramah dan dialog interaktif untuk mensosialisasikan bagaimana menganalisis kegiatan usaha secara mandiri.

Metode yang digunakan dalam pengabdian ini melalui beberapa tahapan yaitu :

1. Tahap observasi kepada kelompok masyarakat yang akan dijadikan khalayak sasaran yaitu kelompok masyarakat petani.

2. Tahap pelaksanan kegiatan adalah penyuluhan dengan mengikutsertakan partisipasi aktif peserta dengan memberikan petunjuk teknis tentang analisis rugi laba dalam menjalan usaha mandiri.

3. Tahap evaluasi pelaksanaan yaitu melakukan ukuran tingkat keberhasilan dari kegiatan yang sosialisasi dan penyuluhan yang sudah dilaksanakan. 


\section{PEMBAHASAN}

Berdasarkan pengamatan pada awal pelaksanaan kegiatan penyuluhan menunjukkan minat yang besar dari peserta yang terlihat dari antusiasme para peserta. Pertanyaan yang diajukan para peserta berkenaan dengan cara menganalisis usaha mandiri sangat rinci, dari format laporan yang harus disiapkan sampai dengan item-item apa saja yang harus dikategorikan pemasukan dan pengeluaran. Tingkat keingintahuan peserta cukup tinggi tentang bagaimana menyusun keuangan mandiri dalam rumah tangga petani.

Dalam melakukan analisis kegiatan usaha mandiri, maka pertama kali yang dilakukan adalah menghitung berapa biaya produksi yang dikeluarkan selama proses produksi berlangsung, dan tambahkan pengeluaran tidak terduga sebagai antisipasi pengeluaran keuangan penting tapi diluar rencana anda. Setelah menginventarisir biaya produksi tersebut, maka dapat dianalisis biaya yang dikeluarkan setiap kali produksi. Setelah semua hari telah diketahui biaya pengeluarannya, maka jumlahkan keseluruhan pengeluran produksi. Pada akhirnya lakukanlah pengeluaran biaya sesuai dengan jumlah produksi yang telah direncanakan, dan hindari pengeluaran biaya diluar itu.

Namun, dibalik keanekaragaman tersebut, mereka semua memiliki satu kesamaan. Mereka memiliki pengetahuan mengenai apa yang harus mereka lakukan terhadap uang yang mereka dapat. Mereka bisa memaksimalkan kegunaan dari uang mereka, serta memanfaatkannya untuk mendapatkan uang lebih banyak lagi.

Setelah diberikan penjelasan tentang penyusunan keuangan mandiri kepada peserta maka pemahaman semakin bertambah sekitar $70-80 \%$. Peserta sangat antusias dan menginginkan diberi petunjuk teknis bagaimana menyusun keuangan mandiri yang sederhana dan praktis dalam keluarga.

Evaluasi kegiatan diukur berdasarkan partisipasi peserta kegiatan dalam setiap tahapan yang dilaksanakan dan terlaksananya rencana kegiatan yang telah disusun. Evaluasi pertama dilaksanakan pada saat penyuluhan dan demontrasi kegiatan yang diberikan kepada peserta kegiatan. Indikator yang digunakan untuk mengukur keberhasilan kegiatan ini adalah: Penyuluhan model partisipasi aktif dan tukar pendapat serta diskusi yang 
dilaksanakan

menunjukkan

pengetahuan masyarakat dan ibu-ibu petani di wilayah desa Tatah Pemangkih Kabupaten Banjar tergolong sedang sekitar 60 - $70 \%$. Dalam melakukan analisis biaya usaha masih menggunakan cara tradisional dalam menghitung berapa biaya produksi yang dihasilkan.

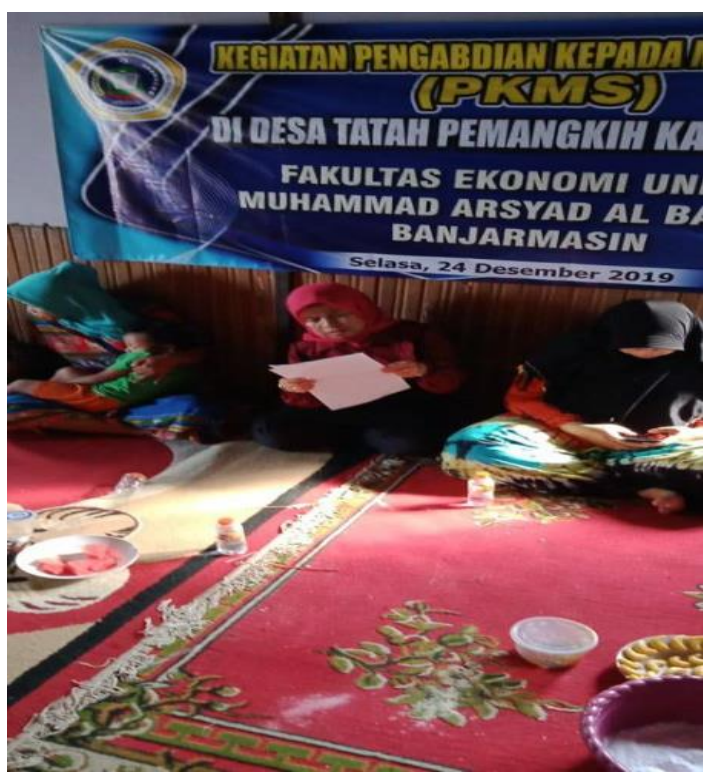

Gambar 1. Suasana saat penyuluhan dan sosialisasi

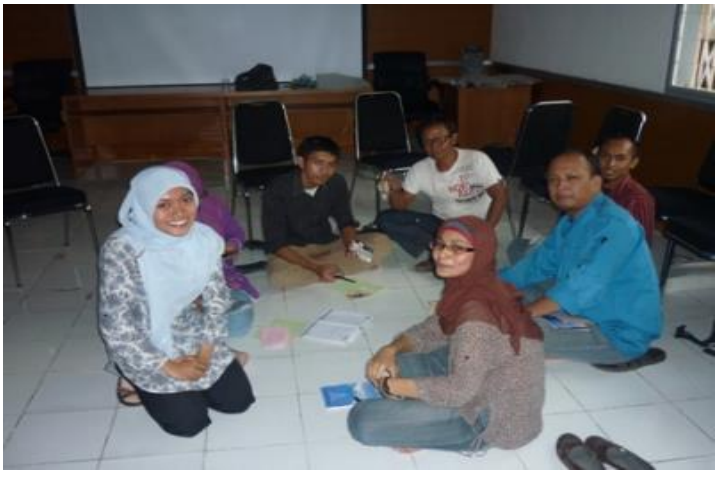

Gambar 2. Peserta sedang latihan menyusun analisis usaha

\section{KESIMPULAN}

Dalam melakukan analisis usaha secara mandiri, maka pertama kali yang dilakukan adalah melakukan pengelompokan biaya-biaya apa saja yang harus dikeluarkan selama proses produksi, dan tambahkan biaya tidak terduga sebagai antisipasi pengeluaran keuangan penting tapi diluar rencana anda. Setelah melakukan analisis biayabiaya tersebut, maka dapat diketahui berapa jumlah biaya pada setiap produksi. Setelah semua hari telah diketahui biaya pengeluarannya, maka jumlahkan keseluruhan pengeluran anda. Pada akhirnya dapat dilakukan analisis biaya produksi sesuai dengan jumlah produksi yang telah direncanakan, dan dapat mengurangi kes alahan perhitungan di luar biaya yang seharusnya, sehingga dapat diperoleh harga yang ekonomis.

\section{DAFTAR PUSTAKA}

Munandar. 2010. "Penganggaran Perusahaan, Teori dan Terapan". Penerbit BPFE-UGM, Jogjakarta

S. Senduk. 2004, "Siapa Bilang Jadi Karyawan Ngak Bisa Kaya; Lima Kiat Praktis Mengelola Gaji Agar Bisa Kaya”, Elex Media Komputindo : Jakarta 
Nafirin, 2012, Teknik Analisis Penganggaran Perusahaan, Erlangga, Jakarta
Check-up Finansial, 3 Langkah Praktis dalam mendeteksi Penyakit Keuangan, 2015, David Chiang, Gramedia elekomindo, Jakarta 